\title{
ENGINEERING MANAGEMENT CONTENT FOR A SENIOR DESIGN COURSE IN MECHANICAL ENGINEERING
}

\author{
P. B. Ravikumar \\ Professor, Mechanical \& Industrial Engineering Department \\ University of Wisconsin, Platteville, WI
}

\begin{abstract}
Mechanical Engineering students at UW-Platteville take the Senior Design Project Course in the final semester of their undergraduate program. Most of the team projects for the course, often all projects, are provided by industry. The course is designed with the primary objective of providing students an experience that serves as a transition from classic engineering education to engineering practice in the real world. To meet this objective, both design and related content essential to the practice of engineering need to be strategically implemented in the course. Related content includes several engineering management topics such as Leadership, Project Management, Time Management, Effective Communication, Human Resources / Relations, and Engineering Ethics. It is a challenge to accommodate such topics due to time constraints or due to the conventional practice of not covering them to a certain degree of rigor. This paper provides a brief overview of the objectives of the Senior Design Project course. The need to relate engineering design and management in such a course is then addressed followed by an in-depth look at the engineering management content that is covered. Teaching / learning strategies adopted in covering the content and assessment strategies used in evaluating the effectiveness are addressed. Non-engineering management faculty planning to introduce engineering management in some of their courses may find some of the material in this paper useful. Faculty who focus on engineering management may find the paper providing some insight and hence ideas of their own as to how engineering faculty approach or must approach the subject of engineering management.
\end{abstract}

\section{OBJECTIVES OF THE SENIOR DESIGN PROJECT COURSE}

The Senior Design Project Course (ME4930) in Mechanical Engineering at the University of Wisconsin-Platteville is offered to Mechanical Engineering majors in their final semester before graduation. It is a required course for all Mechanical Engineering majors. The course is centered around industry sponsored team design projects. In conjunction with the design projects, instruction/learning on engineering design and related content such as engineering management are emphasized. The manner of conducting the design projects and teaching the subject matter are aimed at achieving the objective of providing a transition for students from conventional engineering education to the practice of engineering in the real world.

\section{WHY ENGINEERING MANAGEMENT IN THE SENIOR DESIGN COURSE ?}

It is often the case that engineering majors start their careers as engineering professionals and then, after a few years, move on to management positions often related to engineering. American Society for Engineering Management (ASEM) defines Engineering Management as "the art and science of planning, organizing, allocating resources, and directing and controlling activities which have a technological component"1. This definition is followed by the statement "Engineering 
Management is rapidly becoming recognized as a professional discipline. Engineering managers are distinguished from other managers by the fact that they posses both an ability to apply engineering principles and a skill in organizing and directing technical projects and people in technical jobs". It is thus very important for the graduating engineering student to recognize that the engineering profession requires technical as well as project/ people management skills. The overall structure of industry sponsored team projects in the Senior Design Project Course is favorable for students to apply technical, people oriented, and project management skills. Such a structure in turn facilitates the planning and implementation of supporting design and engineering management course content.

At this final stage of the undergraduate program, design content in the course is more of a final review of design processes and methods. Particular attention is drawn to the inclusion of real world aspects such as economic, social, ethical and aesthetic considerations. Engineering management content in the course can be characterized as practical and complementary to the design processes and methods. Specific engineering management content and methods of teaching / learning / assessing such content in the Senior Design Project Course are described in the rest of this paper.

\section{ENGINEERING MANAGEMENT CONTENT IN THE COURSE}

The following topics are listed in a typical course focusing on engineering and technology management at graduate level: critical issues in the management of engineering and technology projects; analysis of time, cost, performance, parameters from the organizational, people and resource perspectives; project planning, evaluation and selection, project selection models; project and matrix organizations; project teams; scheduling; budget and schedule control; termination of projects ${ }^{2}$. In comparison to the graduate level course, it is obvious that the depth and scope of coverage need to be limited in the Senior Design Project course. Yet the breadth and scope of coverage of engineering management content in the course is relatively deep within the mechanical engineering program. This is because there is very limited exposure to the topic in other courses in the program at the present time. It is recognized though that each of the topics covered can be taught over much longer time periods and in much greater depth. It needs to be pointed out that other engineering programs in the college address engineering management content, some at a good level because of the nature of their field such as industrial engineering, but most are at a basic but developing mode at present.

There are different avenues by which the student is able to learn and implement engineering management aspects in the course. The manner in which the professor manages the course overall, especially the various projects and student teams, is itself a management case study for the shrewd student. It is thus important for the professor to set an example by managing the course, projects, and teams in a professional and thorough manner. Throughout the semester, students also deal with management aspects such as leadership, project selection, budget, schedule, communication with other team members and industry contacts, and overall management during the progression of the projects. These activities are an implicit learning experience in engineering management. When the implicit decisions and experiences are

Proceedings of the 2002 American Society for Engineering Education Annual Conference \& Exposition Copyright $@$ ( 2002, American Society for Engineering Education 
supported by formal education in engineering management through lectures and other forms of learning, the graduating engineer is well prepared to efficiently take on real world engineering tasks. The topics covered through formal education in engineering management are selected from a variety of sources both in content and formats ${ }^{3,4,5,6,7,8,9,10}$. These include books, web sites, and video tapes. Lectures, discussions, and student feedback for assessment of their learning the topics are done almost weekly in conjunction with the logistics of managing the industry projects. Some of the formal topics and the manner of covering them are discussed next. Each of the topics requires about a two-hour session to cover. Six to eight such two-hour sessions are typically required in a semester to cover all the engineering management related content.

\section{Time Management}

Time is a resource similar to other resources that are budgeted, controlled, and managed. Time management not only recognizes this aspect but emphasizes that unlike other resources, time is available equally to one and all. Although such aspects appear to be rather routine and mundane, like so many other aspects of effective engineering management, it is important to recognize many such simple but important considerations. Even a simple check list of such considerations to be gone through can be effective. Students are taught such simple and yet effective list of time management considerations. They are also exposed to other aspects of time management such as the alternatives that enhance the effectiveness of time management when reporting to a supervisor, general rules for effective time management, and identification and use of personal and co-workers' energy levels during a day to increase personal and inter-personal efficiencies. Students are presented with both theory and visual materials such as videos in this area for a better understanding of time management. They are also asked to turn in completed handouts that help them better understand time management.

\section{Human Relations / Resources}

The subject of human relations / resources has a wealth of valuable literature from well known authors in the field. Early works by Frederick Taylor and subsequent contributions from

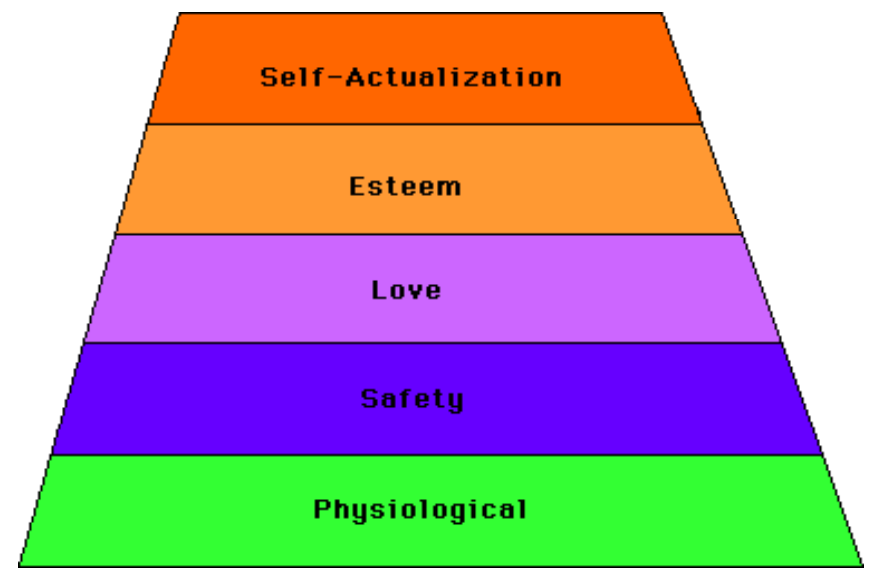

Fig. 1 Abraham Maslow's Hierarchy of Need 
authors such as Abraham Maslow (Maslow's Hierarchy of Needs) ${ }^{5,6}$, Douglas McGregor (Theory of X and Y managers) ${ }^{7}$, and Frederick Herzberg (studies on human motivation factors) ${ }^{4,8}$ to name a few have all provided valuable insights into the subject of human relations / resources. Imporartant aspects of such literature (such as the Hierarchy of Needs as shown in Fig. 1) are shared with students in the form of lectures, discussions, video tapes, and student responses. Current issues in this area such as personality traits, management styles, organizational climate, leadership capabilities, management potential, supervisory effectiveness, human resources or casting, and succession planning are also shared with the students.

Product Liability and Ethical Dynamics Lectures, notes and case studies on product liability and engineering ethics are shared with the students. They are then asked to discuss each case study and respond to a questionnaire. It must be pointed out that such questionnaires or surveys or comments are obtained from students on most of the other topics covered in this paper. As part of the assessment of teaching/ learning, students fill out an assessment questionnaire also at the end of the semester. Sample Questionnaires I shown below is an example on Product Liability and Ethical Dynamics.

PRODUCT LIABILITY AND ETHICAL DYNAMICS
SCENARIO I : Dumping Sub-Standard Parts on the International Market
Challenge 1
Brief Background (Watch video tape for details):
Product is known to be defective, capable of causing electric shock or even electricution.
Choices :
a. Scrap the units and take the loss
b. Sell the units in third world countries with no comparable saftety standards
c. $\quad$ Other
What is your recommendation? Why?
Challenge 2
Brief Background (Watch tape for details):
You are offered one of the defective units which is very useful to you at no cost provided you
sign a release of liability.
Choices:
a.
b.
c. Comment on the company wide offer
What is your recommendation? Why?
Other

Sample Questionnaire I

Proceedings of the 2002 American Society for Engineering Education Annual Conference \& Exposition Copyright $@$ 2002, American Society for Engineering Education 
Effective Communication

Verbal and non-verbal communication can be enhanced through an awareness of the communication process, its elements, and an effort to participate better within such a model by understanding related parameters. Barriers that create communication problems between sender and receiver, Jehari's window ${ }^{9}$ model to overcome such barriers, requirements in business writing, appropriate styles of writing, and factors to consider in good oral reporting and presentation are some of the topics covered in this area.

Dealing with People

The Senior Design Project course emphasizes the importance of people dynamics just as much as engineering dynamics ! Students are introduced to preliminary but formal topics on social dynamics and the factors underlying such dynamics. For example, Robert Bramson's categorization of different people ${ }^{10}$ and the manner of coping with them are a useful study in the area of dealing with people. Students learn such topics. They are also made aware of assessing their own category to better interact with other people. This brings up the aspect of self-assessment as a more detailed study. Self-assessment topics by authors such as Paul J. Meyers, Zig Ziglar, and Willie D. Larkin are shared with students. Students are asked to respond to questionnaires in the area of dealing with people. Sample Questionnaire II below shows one such example.

\section{DEALING WITH DIFFICULT PEOPLE SEMESTER : _ Y YEAR :}

In this segment, we will learn about "what is meant my difficult people", "how to cope with difficult people", and "how not to be a difficult person ourselves" !

Take some notes on "What is meant by difficult people" as you watch the videotape.

Note the types of difficult people as per Robert Bramson :

1.

2.

3.

4.

5.

6.

7.

Note that people may be a mix of the above types as well.

What does "Coping" mean in the context of today's discussion?

Proceedings of the 2002 American Society for Engineering Education Annual Conference \& Exposition Copyright $@$ 2002, American Society for Engineering Education 
What are the basic steps of effective coping ?

1.

2.

3.

5.

4.

6.

As an example of having coping plans to deal with difficult people, what are the steps in the coping plan to deal with the Sherman Tank type of difficult people as per Robert Bramson: 1. 2.

3.

4.

6.

5.

7.

8.

In the discussion on the topic of "how not to be a difficult person yourself", four defensive behaviors to avoid are identified. They are : 1. 2.

3. 4.

WITHOUT USING ANY PERSONAL NAMES AND REFERRING TO THE SEVEN TYPES OF DIFFICULT PEOPLE, identify difficult behavior of your team members in the table below. Do so by placing an $\mathrm{X}$ and a percentage of that pattern of difficult behavior (100\% means maximum) for EACH OF YOUR TEAM MEMBERS (INCLUDING) YOURSELF IN THE FIRST COLUMN). Leave a blank the cells that you believe are $0 \%$.

\begin{tabular}{|c|l|l|c|c|c|}
\hline & Yourself & $\begin{array}{c}\text { Team } \\
\text { Member }\end{array}$ & $\begin{array}{c}\text { Team } \\
\text { Member }\end{array}$ & $\begin{array}{c}\text { Team } \\
\text { Member }\end{array}$ \\
\hline Type 1 & Hostile-Aggressive & & & & \\
\hline Type 2 & Complainers & & & & \\
\hline Type 3 & Silent and Unresponsive & & & & \\
\hline Type 4 & Super-Agreeables & & & & \\
\hline Type 5 & Negativists & & & & \\
\hline Type 6 & Know-it All Experts & & & & \\
\hline Type 7 & Indescisives & & & & \\
\hline
\end{tabular}

Sample Questionnaire II

Proceedings of the 2002 American Society for Engineering Education Annual Conference \& Exposition Copyright $@$ 2002, American Society for Engineering Education 


\section{CONCLUSIONS}

The Senior Design Project Course in Mechanical Engineering at the University of Wisconsin Platteville is structured to enable industry sponsored projects to be undertaken by teams of students. The course has the objective of providing the transition for the graduating student from engineering education to the practice of engineering in the real world. This requires strategic incorporation of engineering management content that students learn and implement during the course as a prelude to practically doing so soon after graduation. This paper has presented some details of the manner in which engineering management has been addressed to accomplish the objectives. Non-engineering management faculty planning to introduce engineering management in some of their courses may find some of the material in this paper useful. Faculty who focus on engineering management may find the paper providing some insight and hence ideas of their own as to how engineering faculty approach or must approach the subject of engineering management.

\section{BIBLIOGRAPHY}

1 http://www.asem.com/geninfo.html\#anchor126352, 2001.

2 http://batam.etm.pdx.edu/courses.asp\#27, 2001.

3 American Society of Mechanical Engineers (ASME) and the Society for Advancement of Management (SAM), "Leadership Training Seminars", 1991/1992.

$4 \quad$ Herzberg, Frederick, "Work and Nature of Man", World Publishing Company, NY, 1966.

$5 \quad$ Maslow, Abraham, "Motivation and Personality", Harper, New York, 1964.

$6 \quad$ http://web.utk.edu/ gwynne/maslow.HTM

7 http://www.accel-team.com/human_relations/hrels_03_mcgregor.html

8 http://www.accel-team.com/human_relations/hrels_05_herzberg.html

9 http://wbarratt.indstate.edu/515/johari.htm

10 Robert Bramson, Ph.D. ,Coping With Difficult People, Simon \& Schuster Sound Ideas, 1992, ISBN: 0671-75874-8

\section{BIOGRAPHY}

Dr. P.B. Ravikumar is Professor of Mechanical and Industrial Engineering at the University of Wisconsin, Platteville. Besides the Senior DesignProject Course, he teaches Manufacturing Processes, Computer Aided Design, Dynamical Systems, Vibration System Design, Mechanical Systems Design and Machine Design. He has more than fifteen years of experience in Mechanical Engineering education and seven years of direct industrial experience in the aerospace and automotive industries. He has worked on several projects from industry such as Boeing, SeaLand, and General Electric. His current areas of interest include Computer Aided Design / Manufacturing with special interest in rational B-Spline mathematics for CAD. Dr.Ravikumar obtained his B.S. and M.S. degrees in Mechanical Engineering from Bangalore University and Indian Institute of Science respectively in India, and his Ph.D. in Mechanical Engineering from Kansas State University. 